\title{
Effectiveness of Using English Module Through Implementation Poster Presentation Aided Vlog to Improve Student Learning Outcomes Information of Students Information System at UPI "YPTK" Padang
}

\author{
Rasmita \\ University of Putra Indonesia YPTK Padang, Indonesia \\ mi2t.caem85@gmail.com.
}

ARTICLE INFO

Article history

Received

Revised

Accepted

Keywords

Effectiveness,

Modules,

Learning Outcomes

\begin{abstract}
This study aims to analyze the effectiveness of the use English modules through the implementation of poster presentations assisted by vlog to improve student learning outcomes in the Information Systems Department at UPI YPTK Computer Science Faculty in Padang. The method used is a mixed method, which combines quantitative and qualitative methods. To achieve the research objectives, the researchers used quasi-experimental design, which involved two groups of participants (control and experimental) in academic year 2017/2018 students majoring in Information Systems, with a purposive sampling technique by taking pre-test, treatment and posttest. The research data were analyzed using the one-sample t-test. The results of the data analysis showed that the pretest and post test scores of the experimental group showed significant differences, while the control group did not show significant differences. This research shows the results that the use of English modules through the implementation of poster presentations assisted by vlog is more effective in improving students' learning outcomes than those not using the module
\end{abstract}

\section{Introduction}

Learning English in college is not only about providing strategic material, topics or concepts, but also must provide a learning experience that enables development of student independence for learning. The one of factor supporting this independence is the availability of adequate learning resources such as the availability of textbooks or teaching materials that are integrated in the course. The results of observations in academic year 2017/2018 obtained several facts, including the learning process of English courses in the classroom which are still relatively common, namely by the lecture method (teacher-centered), the media is used in the form of blackboards, power points and copies of material from books published abroad. which looks complex and difficult for students to understand. In the teaching and learning process, students only listen to explanations of material from the lecturers, copy back what the lecturers has said and do the practice questions, so that the English mark rate is less satisfactory, only reaching $40 \%$ of students each year with satisfactory grades in the course.

Based on the facts above, it is necessary to evaluate the implementation of lecture activities in English courses and examine the causes. After observing, the low student learning outcomes are due to several factors, namely: (1) the large amount of English material does not correspond to the number of meetings in the classroom, (2) the large number of students in the class that does not allow for individual practice, (3) low student interest in learning due to monotonous learning methods.

To overcome various factors that cause low learning outcomes, and increase student interest and motivation in English, it is necessary to change the pattern of learning approaches into student centers to make students more active in lecturing activities and the use of teaching materials that are right on target in learning English for students who are not from the English department. The solution offered is in the form of implementing poster presentations assisted vlog for students in understanding and processing 
English learning materials. The reason for choosing this poster presentation assisted by vlog, because of its effective and massive benefits.

Poster as one of the media publication or dissemination of information in the form of two dimensions in it consists of writing, drawing or a combination of both with the aim of providing information to people who see or read it. According to KBBI (2007) posters are placards installed in public places (in the form of announcements, or advertisements). Moreover, Susilana and Riana (2009) suggest that posters are a clear, conspicuous visual combination presentation to attract people's attention easily.

Many researchers such as Throne and Black (2011) have made a number of observations and concluded that teachers and students can obtain a better learning atmosphere with the online learning process. Using vlogs in language learning is a recommended one because students can attend various subject matter and discuss them. Indirectly this activity can build good team interaction and collaboration between students (Bryant, 2006). Poster Presentation is conducted by students in the class to deepen understanding of basic English material and practice it directly. While the vlog can be used as a medium of discussion and review for the material that has been studied. From the explanation above, it can be concluded that the two integrated media can also provoke students' creativity and enthusiasm in learning English so that the learning outcomes obtained later can be better than before.

Meanwhile, modules are programmed learning materials arranged in such a way that are presented in a systematic, detailed and integrated manner (Daryanto, 2013). In addition, Susilana and Riyana (2009) also mentioned that the module is a package of programs that are arranged and designed in such a way as to benefit learners' learning. Student experience is used as an approach in learning modules. From the above understanding it is concluded that the module is a learning tool or facility containing specific material aimed at students being able to learn independently, and ways to evaluate that are designed systematically, as well as interesting to achieve the learning objectives.

In addition, learning outcomes are abilities obtained by students after going through the process of learning activities. Arikunto (2010) states that learning outcomes are changes in student behavior seen in terms of cognitive, affective and psychomotor after they do the learning process.

There are some researcher who have been conducted research related to the effectiveness of the use of modules, namely I Nyoman Sukra (2016) with the results of his research that learning by using new English teaching materials as a result of development is effective for increasing student learning activities and creativity rather than using old teaching materials. Furthermore, Tutut Wahyuningrum (2019), entitled the effectiveness of the use of modules to increase student final grades in English lessons. The results of his study showed the average score of the final group of students who were given the module was higher than the average final score of the group of students who were not given a module, carried out on class XA and XB students in state Vocational High School 3 academic year 2016/2017, so the results of giving titles were very effective in increasing grades end of students.

\section{Method}

This type of research is an experimental study using the Quasi Experimental Design. In this study, researchers used a mixed method, to collect and analyze quantitative and qualitative data (Crewell \& Plano Clark, 2006). In this study there is a trial treatment and analyze the effects of these treatments. The population in this study were students majoring in information systems at the Faculty of Computer Science UPI YPTK Padang in academic year of 2017/2018, with a purposive sampling technique. The writer took 40 students belong to experimental group and 40 students in control group. To analyze the results of its effectiveness using pre-test and post-test one group design data, using the t-test formula ( Arikunto, 2010):

$$
t=\frac{M d}{\sqrt{\frac{\Sigma(x d)^{2}}{N(N-1)}}}
$$

Keterangan :

Md $\quad$ : the mean of devision (d) between post- test and pre- test

$\mathrm{Xd} \quad$ : difference in deviation from mean deviation 


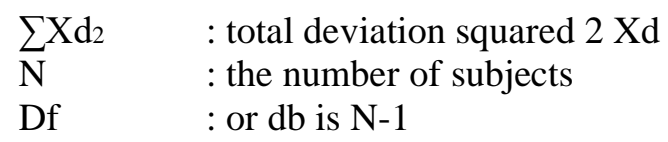

The formula is used for the research design of a single subject, that is, the observations carried out when the subject has not been treated and after the subject has been treated. The results of this data are analyzed using the t-calculation formula and show whether the treatment given is effective or not.

\section{Finding and Discussion}

The effectiveness testing in this study was conducted in two ways, namely testing the differences in the pretest and posttest learning outcomes of learning outcomes before and after applying English modules assisted by poster presentation and vlog testing the differences in learning outcomes of the control group that studied using the old (conventional) modules and the learning group using the differences in outcomes module is explained in the following sections:

A. Test Difference in Pretest Posttest Learning Outcomes

Before conducting this test, the Normality Test data is performed through the KormogorovSmirnov (KS) Test, with the following results:

Table 1. Test Result for Data Normality

\section{One-Sample Kolmogorov-Smirnov Test}

\begin{tabular}{|c|c|c|c|c|c|}
\hline & & $\begin{array}{l}\text { Pretest__ } \\
\text { Control }\end{array}$ & $\begin{array}{l}\text { Postest__ } \\
\text { Control }\end{array}$ & $\begin{array}{l}\text { Pretest_- } \\
\text { Exsperiment }\end{array}$ & $\begin{array}{l}\text { Postest_- } \\
\text { Exsperiment }\end{array}$ \\
\hline \multicolumn{2}{|l|}{$\mathrm{N}$} & 40 & 40 & 40 & 40 \\
\hline \multirow[t]{2}{*}{ Normal Parametersa } & Mean & 47.70 & 69.22 & 48.95 & 72.80 \\
\hline & $\begin{array}{l}\text { Std. } \\
\text { Deviation }\end{array}$ & 13.211 & 10.519 & 19.119 & 14.807 \\
\hline \multirow{3}{*}{$\begin{array}{l}\text { Most } \\
\text { Differences }\end{array}$} & Absolute & .095 & .146 & .111 & .150 \\
\hline & Positive & .095 & .146 & .111 & .127 \\
\hline & Negative & -.080 & -.080 & -.073 & -.150 \\
\hline \multirow{2}{*}{\multicolumn{2}{|c|}{$\begin{array}{l}\text { Kolmogorov-Smirnov Z } \\
\text { Asymp. Sig. (2-tailed) }\end{array}$}} & .601 & .921 & .704 & .951 \\
\hline & & .863 & .364 & .705 & .327 \\
\hline \multicolumn{2}{|c|}{ a. Test distribution is Normal. } & & & & \\
\hline
\end{tabular}

Based on the description of the results of the normality data analysis results with the KS test above, it can be explained that all data to be tested has a Normal data distribution, because it has an Asymp Sig value. (2-tailed) which is $>0.050$. Pretest control group) 0.863, Posttest control group 0.364, Pretest experimental group 0.705 and posttest experimental group 0.327 . Thus it can be interpreted that all data groups have normal data distribution and meet the normality requirements in conducting the $t$ test.

Test differences in the results of the pretest and posttest intend to find out the difference in results and improvement in learning outcomes obtained by the control group and the experimental group by using two different learning modules. The results of the analysis in the Control group can be seen in the following Table 2: 
Table 2. Results of Pretest and Posttest Control Group Analysis

\section{Paired Samples Test}

\begin{tabular}{|c|c|c|c|c|c|c|c|c|}
\hline & \multicolumn{5}{|c|}{ Paired Differences } & \multirow[b]{3}{*}{$\mathrm{t}$} & \multirow[b]{3}{*}{ Df } & \multirow{3}{*}{$\begin{array}{l}\text { Sig. } \\
\text { (2-tailed) }\end{array}$} \\
\hline & \multirow[b]{2}{*}{ Mean } & \multirow{2}{*}{\begin{tabular}{|l} 
Std. \\
Deviatio \\
$\mathrm{n}$
\end{tabular}} & \multirow{2}{*}{$\begin{array}{l}\text { Std. } \\
\text { Error } \\
\text { Mean }\end{array}$} & \multicolumn{2}{|c|}{$\begin{array}{l}95 \% \text { Confidence } \\
\text { Interval of the } \\
\text { Difference }\end{array}$} & & & \\
\hline & & & & Lower & Upper & & & \\
\hline $\begin{array}{r}\text { Pair } 1 \text { Pretest__ } \\
\text { control } \\
\text { Postest_- } \\
\text { control }\end{array}$ & $\begin{array}{l}21.52 \\
5\end{array}$ & 15.215 & 2.406 & 26.391 & 16.659 & 8.948 & 39 & .000 \\
\hline
\end{tabular}

Based on Table. 2 stated above can be explained that the results of testing the differences in the pretest and posttest learning outcomes of the control group have a score of $t$ arithmetic $>t$ table $(\mathrm{df}=39)$, with a value of $8,948>2,021$. Because $t$ arithmetic $>t$ table it is stated that there are differences in learning outcomes before (pretest) and after (posttest) learning using conventional learning modules. The average improvement in learning outcomes can be seen in Table 3. Below:

Table 3. The Difference in Average Result of Control Group (Pretest -Postest)

Paired Samples Statistics

\begin{tabular}{|ll|l|l|l|l|}
\hline & & Mean & N & Std. Deviation & Std.Error Mean \\
\hline Pair 1 & Pretest_control & 47.27 & 40 & 13.211 & 2.089 \\
& Postest_control & 69.22 & 40 & 10.519 & 1.663 \\
\hline
\end{tabular}

Based on the table above, it can be seen that the learning outcomes of the control group during the pretest was 47.27 and when the posttest was 69.22. Learning outcomes increased by 21.95 scores. The results of the analysis in the Experiment group can be seen in the following Table 4:

Table 4. Results of Pretest and Posttest Analysis of the Experiment Group

Paired Samples Test

\begin{tabular}{|c|c|c|c|c|c|c|c|c|c|}
\hline & & \multicolumn{5}{|c|}{ Paired Differences } & \multirow[b]{3}{*}{$t$} & \multirow[b]{3}{*}{$\mathrm{df}$} & \multirow{3}{*}{$\underset{\text { Sig. }}{\text { (2-tailed) }}$} \\
\hline & & \multirow[b]{2}{*}{ Mean } & \multirow{2}{*}{$\begin{array}{c}\text { Std. } \\
\text { Deviation }\end{array}$} & \multirow{2}{*}{$\begin{array}{l}\text { Std. } \\
\text { Error } \\
\text { Mean }\end{array}$} & \multicolumn{2}{|c|}{$\begin{array}{l}\text { 95\% Confidence } \\
\text { Interval of the } \\
\text { Difference }\end{array}$} & & & \\
\hline & & & & & Lower & Upper & & & \\
\hline Pair 1 & $\begin{array}{l}\text { Pretest__ } \\
\text { Eksperimental } \\
\text { Postest_- } \\
\text { Eksperimental }\end{array}$ & 30.700 & 13.838 & 2.188 & -35.126 & 26.274 & 14.031 & 39 & .000 \\
\hline
\end{tabular}

Based on Table 4 stated above, it can be explained that the results of testing the differences in the pretest and posttest learning outcomes of the experimental group had a t-count $>\mathrm{t}$-table $(\mathrm{df}=39)$, with a value of 14,031>2,021. Because $t$ arithmetic $>\mathrm{T}$ table then it is stated that there are differences in learning outcomes before (pretest) and after (posttest) learning outcomes using the learning module poster assisted vlog. The average improvement in learning outcomes can be seen in Table 6 below: 
Table 5. The Difference in Average Results of Experimental Groups (Pretest-Postest)

\section{Paired Samples Statistics}

\begin{tabular}{|ll|l|l|l|l|}
\hline & & Mean & $\mathrm{N}$ & Std. Deviation & Std. Error Mean \\
\hline Pair 1 & Pretest_Eksperimental & 48.95 & 40 & 19.119 & 3.023 \\
& Postest_Eksperimental & 79.65 & 40 & 12.831 & 2.029 \\
\hline
\end{tabular}

Based on the table above, it can be seen that the experimental group learning outcomes at pretest are 48.95 and at posttest is 79.65 . Learning outcomes increased by 30.70 scores. The degree of difference in results can be illustrated in the following histogram:

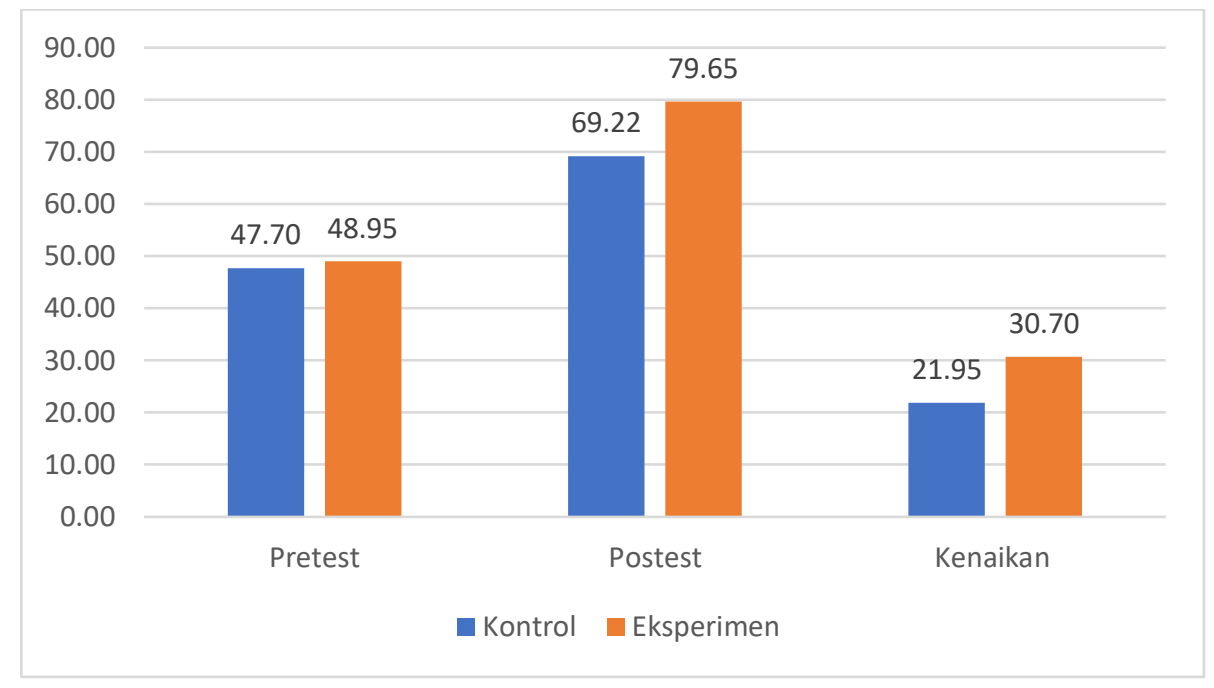

Fig. 1. Difference in Average Results and Difference in Pretest Posttest

Based on the histogram of the difference in the average results and the difference in the pretest posttest scores in the two groups it can be stated that the control group had an increase in learning outcomes by 21.95 scores while students who studied with the poster presentation module assisted by vlog had an increase in learning outcomes score of 30.70 . This means that students are better able to improve learning outcomes by using the poster presentation assisted by vlog.

B. Test the Difference between Experimental and Control Learning Outcomes

To find out the differences in learning outcomes between the control and experiment groups a different test was performed using the Independent sample t-test. Before conducting this test homogeneity test data is performed to see whether the experimental and control sample groups have the same ability statistically, Homogeneity test results can be explained as follows: 
Table 6. Homogeneity test result

\section{Test of Homogeneity of Variances}

Result
\begin{tabular}{|l|l|l|l|}
\hline $\begin{array}{l}\text { Levene } \\
\text { Statistic }\end{array}$ & df1 & df2 & Sig. \\
\hline 2.550 & 1 & 78 & .091 \\
\hline
\end{tabular}

The results of homogeneity testing of data through Levene Statistics indicate that the value of the Significance count 0.091 , this score $>0.050$ which means that both groups of data have homogeneous score characteristics. For this reason, different test can be done through independent sample t test to test the proposed hypothesis. The results of the $t$ test analysis can be seen in table 7 below:

Table 7. Different Test Results of Experimental and Control Group Learning Outcomes

\section{Independent Samples Test}

\begin{tabular}{|c|c|c|c|c|c|c|c|c|}
\hline & \multicolumn{2}{|c|}{$\begin{array}{l}\text { Levene's Test } \\
\text { for Equality of } \\
\text { Variances }\end{array}$} & \multicolumn{5}{|c|}{ t-test for Equality of Means } \\
\hline & & $\mathrm{F}$ & Sig. & $\mathrm{T}$ & df & $\begin{array}{l}\text { Sig. } \\
\text { tailed })\end{array}$ & $\begin{array}{l}\text { Mean } \\
\text { Difference }\end{array}$ & $\begin{array}{l}\text { Std. Error } \\
\text { Differenc } \\
\text { e }\end{array}$ \\
\hline \multirow[t]{2}{*}{ Result } & $\begin{array}{l}\text { Equal variances } \\
\text { assumed }\end{array}$ & \multirow[t]{2}{*}{3.522} & \multirow[t]{2}{*}{.064} & 3.974 & 78 & .000 & 10.425 & 2.623 \\
\hline & $\begin{array}{l}\text { Equal variances } \\
\text { not assumed }\end{array}$ & & & 3.974 & 75.110 & .000 & 10.425 & 2.623 \\
\hline
\end{tabular}

The results of testing the hypothesis through the independent sample $t$ test above show the results that $\mathrm{t}$ arithmetic $>\mathrm{t}$ table $(\mathrm{df}=78)$ with a score of 3,974>1,990, thus the hypothesis that reads there are differences in learning outcomes of students who learn modules by using poster presentation assisted by vlog, its better than students who learn to use ordinary modules (conventional) at a significance level of $95 \%$. For this reason, it is stated that this module is effectively used to improve student learning outcomes in English.

\section{Conclusion}

Based on the average grade of the two groups, the experimental group taught using the English teaching module through the implementation of poster presentations assisted vlog,it's better which showed results with an average of 30.70, while the average value of the class for the control group taught without modules teaching English through the implementation of poster presentations -assisted vlog gained a score of 21.95. This shows the experimental group learning outcomes using teaching modules that have been developed better than the control group taught without use the module with a difference of 8.75 points.

\section{References}

[1] Arikunto, Suharsimi. 2010. Prosedur Penelitian Suatu Pendekatan Praktik. Jakarta: Rineka Cipta 2010. Manajemen Penelitian. Jakarta: Rineka Cipta

[3] Bryant, Throne. 2006. Using World of Warcraft and other MMORPGs to foster a targeted, social and cooperative approach toward language learning..Available at: htmp// www.academiccommons.org/commons/essay/bryant-MMORPGs-forSLA. (Accessed Desember 20,2019) 
[4] Creswell, J. W., \& Plano Clark, V. L. 2006. Designing and conducting mixed methods research. Thousand Oaks, CA: Sage

[5] Daryanto. 2013. Media Visual untuk Pengajaran Teknik. Bandung: Tarsinto

[6] I Nyoman Sukra. 2016. Efektifitas Buku Ajar Bahasa Inggris Berbasis Kompetensi Dalam Meningkatkan Hasil Belajar Mahasiswa. Jurnal Sosial dan Humaniora(Journal of social sciences and humanities),Vol 6, No 2, 2016. Available at:http://ojs.pnb.ac.id/index.php/SOSHUM/article/view/202. (Accessed Desember 25, 2019)

[7] Kamus Besar Bahasa Indonesia (KBBI). 2007. Poster. Jakarta: Depdiknas

[8] Susilana, R. dan Cepi Riyana. 2009. Media Pembelajaran.Bandung: Wacana Prima

[9] Throne, S.L., and Black, R.W. 2011. Identity and Interaction in Internet-mediated contexts. In Higgins, C. (ed) Identity Formation in Globalizing Contexts. New York: Mouton de Gruyter.

[10] Tutut Wahayuningrum.2019.Efektivitas Penggunaan Modul terhadap Peningkatan Nilai Akhir Siswa Pada Pelajaran Bahasa Inggris. Artikel terbit di Jurnal Dinamika Bahasa dan Budaya, Pengembangan Ilmu Bahasa dan Budaya $\quad$ Semarang, Vol $14 \quad$ No 1. Available at: https://www.unisbank.ac.id/ojs/index.php/fbib1/article/view/6710 (Accesed Desember 25, 2019) 